\title{
Perbaikan Stabilitas Dinamik Sistem Tenaga Terintegrasi Pembangkit Listrik Tenaga Mikro Hidro dan Diesel Menggunakan PSS Berbasis ANFIS
}

\section{Improvement of Dynamic Power System Stability Integrated to Micro Hydro and Diesel Power Plants using PSS Based on ANFIS Method}

\author{
I.M. Ginarsa*, I.M.A. Nrartha, S. Sultan, A.B. Muljono dan S. Nababan \\ Dept. of. Electrical Eng., Fakultas Teknik, UNRAM, Nusa Tenggara Barat, INDONESIA. \\ Tel. +62-0370 632125, Fax. +62-0370 632125 \\ *corresponding author, email: kadekgin@unram.ac.id
}

Manuscript received: 28-10-2020. Accepted: 17-12-2020

\begin{abstract}
ABSTRAK
Unit-unit pembangkit listrik dibangun dekat dengan pusat-pusat beban sebagai regulasi Sistem Tenaga Listrik (STL). Unit pembangkit yang dibangun umumnya berkapasitas kecil sehingga transfer daya inter dan antar area menjadi lebih mudah. Penelitian ini bertujuan untuk memperbaiki stabilitas dinamik pembangkit listrik tenaga mikrohidro (PLTMH) menghadapi perubahan beban pada sistem yang terintegrasi dengan pembangkit listrik tenaga diesel (PLTD). PLTD dilengkapi dengan Power System Stabilizer (PSS) berbasis ANFIS untuk perbaikan stabilitas dinamis sistem tenaga. PSS berbasis ANFIS tipe Sugeno menggunakan 2 input dengan fungsi keanggotaan Gauss2mf dan jumlah masing-masing fungsi keanggotaan adalah 5. Hasil simulasi menunjukkan kenaikan beban 5\% pada PLTD dapat mengurangi peak overshoot perubahan sudut daya PLTD yaitu dari 0,023 menjadi 0,0138 dan $0,0132^{\circ}$; dan pengurangan waktu setling dari $>6$ menjadi 4,051 dan 3,553 s, masing-masing untuk PLTD tanpa PSS, PSS konvensional dan PSS berbasis ANFIS. Hasilhasil simulasi menunjukkan bahwa PSS berbasis ANFIS lebih efektif memperbaiki stabilitas dinamik dibanding dengan PSS lainnya.
\end{abstract}

Kata kunci : Listrik; PLTMH; PSS; perbaikan; respon

\footnotetext{
ABSTRACT

Power generating units should be built closed to load centers according to electric power company regulation. These units are generally small in capacity, so that makes power transfer among interand outer-areas is easier to be done. This study aims to improve dynamic stability of a Micro Hydro Power Plant (MHPP) on perspective of 5\% load increased in Diesel Power Plant (DPP). The DPP is equipped by an ANFIS-based Power System Stabilizer (PSS) in this scheme. Two inputs with Gauss2mf membership function (MF) type and 5-number of the each MF are used to implement the
} 
ANFIS model. Simulation results show that overshoot of MHPP power angle deviation is reduced to the values of $0.023,0.0138$ and $0.0132^{\circ}$, for the DPP without PSS, conventional and ANFIS PSS, respectively. Also, reduction in setting time is achieved at times $>6,4.051$ and $3.553 \mathrm{~s}$. It is shown that the ANFIS PSS is more effective to enhance the dynamic stability compared to other PSS.

Keywords: Electricity; improve; MHPP; PSS; response

\section{PENDAHULUAN}

Transfer daya lebih mudah dengan beroperasinya unit-unit pembangkit tersebar/distributed generation (DG). Transfer daya mempertimbangkan lama dan keberagaman yang kompleks dari pada integrasi struktur peralatan secara vertikal (Ilik dkk, 1998; Ilik dkk, 2000). Hal ini membawa dampak fluktuasi perubahan titik operasi dan pola aliran daya yang menyebabkan permasalahan pada stabilitas dinamis sistem tenaga (Kundur, 1994), juga stabilitas tegangan (Canizares, 2000; William dan Stevenson, 1982) pada STL secara umum. Sistem Kelistrikan Lombok (SKL) memiliki beberapa unit pembangkit berupa generator sinkron yang lokasinya tersebar pada pusat-pusat beban dan terkoneksi ke sistem di level distribusi $20 \mathrm{kV}$ (PLN, 2005). Stabilitas dinamis sistem terutama masalah ketidakstabilan inter- atau antar-area perlu menjadi perhatian untuk memastikan sistem beroperasi secara kontinyu. SKL disuplai oleh beberapa pembangkit listrik tenaga diesel (PLTD) dan satu buah pembangkit listrik tenaga mikro hidro (PLTMH) yang digunakan pada penelitian ini. Operasinya PLTMH pada SKL sebagai pembangkit cadangan yang dioperasikan pada saat musim penghujan. Masuknya DG dalam sistem diperkirakan akan semakin berkembang. Oleh karena itu perhatian bergeser ke arah mempertimbangkan efek kumulatif pada sistem tenaga utama akibat adanya level kapasitas DG yang signifikan. Dapat diperkirakan bahwa DG ukuran besar akan memberikan dampak secara global atau sistem yang sampai kini belum begitu dipahami secara penuh. Pengaruh DG tidak hanya terbatas pada sistem distribusi tetapi lebih banyak menaruh perhatian pada dampak DG terhadap stabilitas sistem secara keseluruhan (Donnelly dkk, 1996). Permasalahan lain yang masih relevan antara lain adalah tentang dampak dari penjadwalan pembangkit terhadap pemenuhan kebutuhan beban nyata, selain itu juga mengenai penyediaan daya reaktif, juga pembangkit cadangan dalam mengantisipasi kontingensi, dan untuk kemampuan pengasutan awal setelah adanya black out (Narang, 2006). Pengaruh unit-unit pembangkit tersebar DG dengan tipe yang berbeda, termasuk generator sinkron pada stabilitas transient dan stabilitas tegangan telah dilakukan pada (Slootweg dan Kling, 2002), (Nikman dkk, 2003) dan pengaruh unit DG skala-besar pada stabilitas sistem tenaga dikerjakan pada (Narang, 2006; Knazkins, 2004; Donelly dkk, 1996; Guttromson, 2002). Masuknya DG ke jaringan listrik mampu memperbaiki stabilitas STL secara signifikan (Lasseter, 2003). Penelitian tentang stabilitas, Hopf bifurcation yang mengakibatkan osilasi pada sistem tenaga listrik (STL) dilakukan pada (Genc dkk, 2003). Aplikasi power system stabilizer (PSS) untuk perbaikan stabilitas sistem tenaga listrik (STL) dikemukakan pada (De Mello dan Cocordia, 1969). Ginarsa (2001) menerapkan PSS pada STL Jawa-Bali Area IV, diperoleh hasil bahwa STL dengan PSS mampu memperbaiki stabilitas sistem. Sebelumnya juga dilakukan penelitian oleh Soeprijanto (1995) dengan lokasi yang lain yaitu STL Jawa-Bali Area II. 
Penelitian aplikasi kecerdasan buatan pada kontrol STL telah dilakukan seperti: Perbaikan stabilitas tegangan menggunakan metode adaptive neuro-fuzzy inference system (ANFIS) (Ginarsa dkk, 2013), perbaikan stabilitas mesin tunggal (Ginarsa dkk, 2014), sistem multimesin (Muljono dkk, 2015) menggunakan ANFIS, dan fuzzy tipe-2 (Ginarsa dkk, 2018), menekan arus transient pada sistem high voltage direct current (Ginarsa dkk, 2018; 2019; 2020). Sementara itu, pemasangan PSS konvensional pada SKL telah mampu memperbaiki stabilitas sistem tersebut (Nrartha dan Muljono, 2010). Tetapi masih ada peluang untuk memperbaiki stabilitas SKL dengan menggunakan PSS berbasis ANFIS, terutama untuk menekan peak overshoot dan memperpendek settling time untuk kecepatan dan sudut rotor. Maka metode ANFIS sangat berpotensi untuk diterapkan pada sistem SKL. Penelitian ini bertujuan untuk perbaikan stabilitas dinamik sistem tenaga terintegrasi PLTMH dan PLTD menggunakan PSS berbasis-ANFIS.

\section{Alat dan Bahan}

\section{BAHAN DAN METODE}

Penelitian ini menggunakan seperangkat personal computer (PC) spesifikasi prosesor Intel Core i5-7400, RAM 8 GB, lengkap dengan CDROM, Mouse, dan komponen pendukungnya. Perangkat-lunak yang akan digunakan dalam penelitian ini adalah Microsoft Windows 10 sebagai sistem operasi, perangkat-lunak MATLAB/Simulink sebagai pengolah data dan pembuatan program untuk simulasi stabilitas Sistem Kelistrikan Lombok yang merupakan sistem tenaga listrik interkoneksi pada level tegangan distribusi $20 \mathrm{kV}$ dengan unit-unit pembangkit yang tidak terpusat (Muljono dan Nrartha., 2009).

\section{Metode}

Penelitian ini adalah mensimulasikan model stabilitas sinyal-kecil untuk SKL dilengkapi dengan power system stabilizer (PSS) berbasis-ANFIS. Yang mana sebelum diperoleh model stabilitas maka diawali dengan menjalankan program aliran daya listrik yang terdapat pada SKL. Berikutnya menyederhanakan model impedansi/admitansi jaringan listrik SKL yang hanya melibatkan bus generator yang terlibat, bus-bus beban direduksi dan beban dianggap statik. Membuat program stabilitas dan membangun model PSS konvensional (kompensasi lead-lag). Berikutnya adalah menggantikan PSS konvensional dengan PSS berbasis-ANFIS untuk perbaikan stabilitas SKL. Adapun SKL yang dipakai dalam penelitian ini diilustrasikan pada Gambar 1.

\section{Desain Power System Stabilizer (PSS) Berbasis ANFIS}

PSS ANFIS dibangun dengan menggunakan algoritma fuzzy tipe Sugeno dan melalui proses pelatihan. Yang mana data pelatihan diperoleh dari menjalankan PSS konvensional yang dijalankan dengan beban pada SKL dan skenario bervariasi. Diagram blok PSS konvensional dapat diilustrasikan pada Gambar 2 (a). Berikutnya, data dari PSS konvensional dibentuk menjadi matriks input-output dengan masing-masing 5000, 4000 dan 3000 titik data untuk data training, testing dan checking. Setelah selesai proses training maka 
model ANFIS yang sudah dilatih ditanam pada PSS-ANFIS (jenis blok: Fuzzy logic control, FLC) seperti pada Gambar 2 (b). Struktur ANFIS yang yang dibangun menggunakan 2 input dan 1 output dan struktur ANFIS ini dapat dilihat pada Gambar 2 (c). Yang mana kecepatan rotor (om) dipakai sebagai input 1, derivatif kecepatan rotor (do) dipakai sebagai input 2, dan output adalah sinyal kompensasi PSS (Vpss). Lima buah fungsi keanggotaan Gauss $2 m f$ digunakan untuk input kecepatan rotor (input 1) diilustrasikan pada Gambar 2 (d). Setelah melalui proses pelatihan dan terbentuk PSS ANFIS, maka tahap selanjutnya adalah pengujian yang dibahas pada sub-bagian berikut.

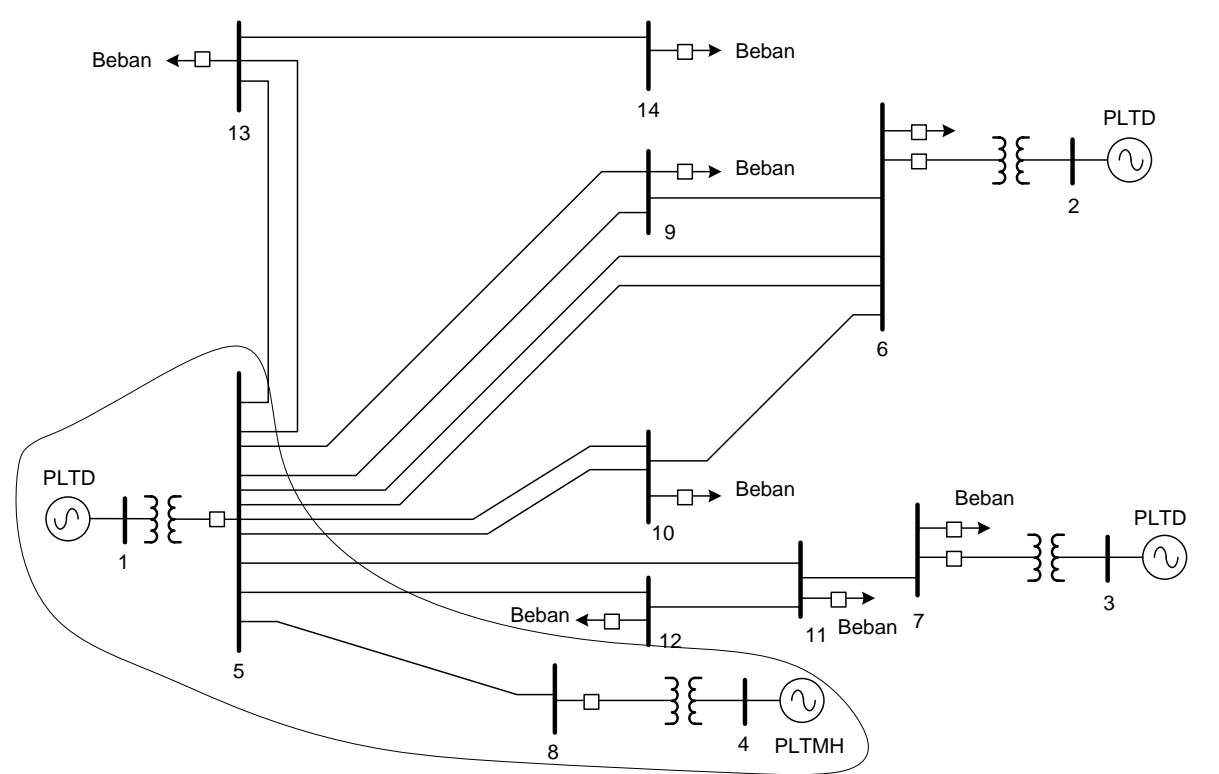

Gambar 1. Sistem yang diteliti (Nrartha dan Muljono, 2010)

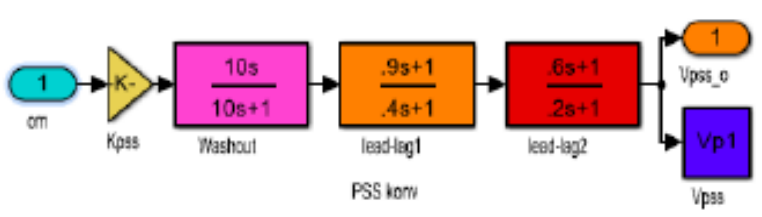

a. PSS konvensional

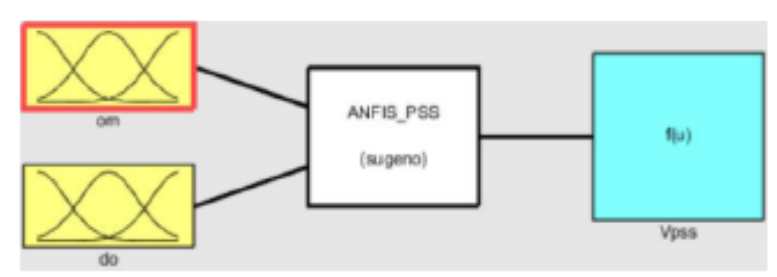

b. PSS ANFIS

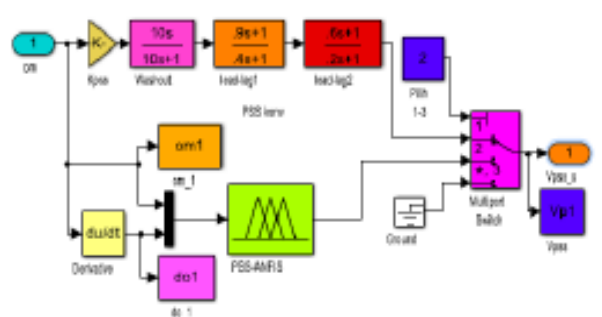

c. PSS ANFIS

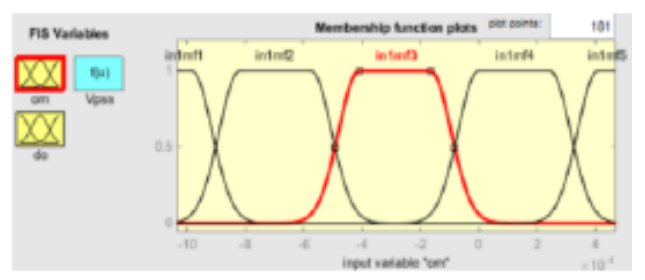

d. PSS kon

Gambar 2. Tahapan desain PSS ANFIS 


\section{Tahapan Pengujian dan Validasi}

Pengujian dilakukan dengan PSS hanya dipasangkan pada PLTD, sedangkan PLTMH tanpa (no) dipasang PSS. Pengujian PSS berbasis ANFIS dilakukan dengan memberi sinyal step sebesar 0,05 pu pada Bus PLTD dan Bus PLMTH yang merepresentasikan kenaikan beban 5\% pada masing-masing bus. Untuk memvalidasi hasil maka PLTD juga dipasangkan PSS konvensional dan tanpa PSS, dan cara pengujian sama dengan pengujian PSS ANFIS. Adapun pengujian masing-masing PSS dibagi menjadi 2 skenario yaitu:

a. Skenario I: Kenaikan beban 5\% pada Bus PLTD.

b. Skenario II: Kenaikan beban 5\% pada Bus PLTMH.

\section{HASIL DAN PEMBAHASAN}

Pada Skenario I: beban di Bus PLTD, respon yang dihasilkan untuk kecepatan rotor adalah seperti Gambar 3-6, Tabel 1 dan 2. Gambar 3 dan Tabel 1 memperlihatkan bahwa respon PSS ANFIS memberikan peak overshoot $\left(M_{p}\right)$ lebih kecil (sebesar $-10,05 \times 10^{-4} \mathrm{rad} / \mathrm{s}$ ) daripada PSS konvensional dan no PSS yang memberikan peak overshoot masing-masing $\left(-11,39\right.$ dan $\left.-14,97 \times 10^{-4} \mathrm{rad} / \mathrm{s}\right)$. Settling time $\left(t_{s t}\right)$ yang diberikan oleh PSS ANFIS adalah pada waktu 2, $91 \mathrm{~s}$. Sementara itu, PSS konvensional dan no PSS yang memberikan settling time pada waktu masing-masing 3,26 dan lebih lama dari 6 s. Gambar 4 dan Tabel 1 memperlihatkan bahwa respon dari PSS ANFIS mampu menekan peak overshoot menjadi lebih kecil daripada PSS konvensional dan no PSS. PSS ANFIS mampu mempercepat settling time daripada PSS konvensional dan no PSS.

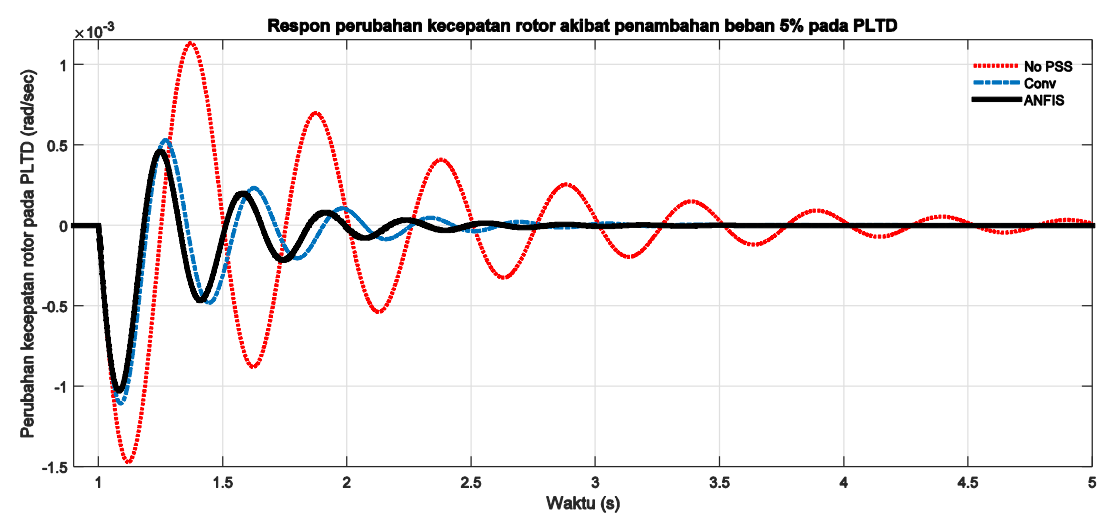

Gambar 3. Perbaikan stabilitas untuk kec. rotor PLTD diuji dengan beban naik 5\% pada bus PLTD 


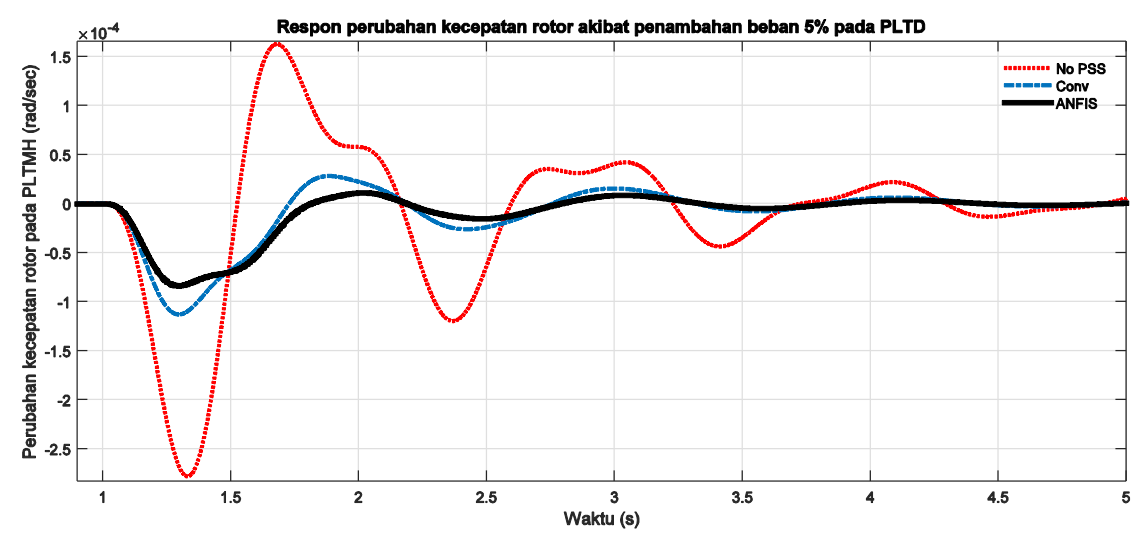

Gambar 4. Perbaikan stabilitas untuk kec. rotor PLTMH akibat beban naik 5\% di bus PLTD

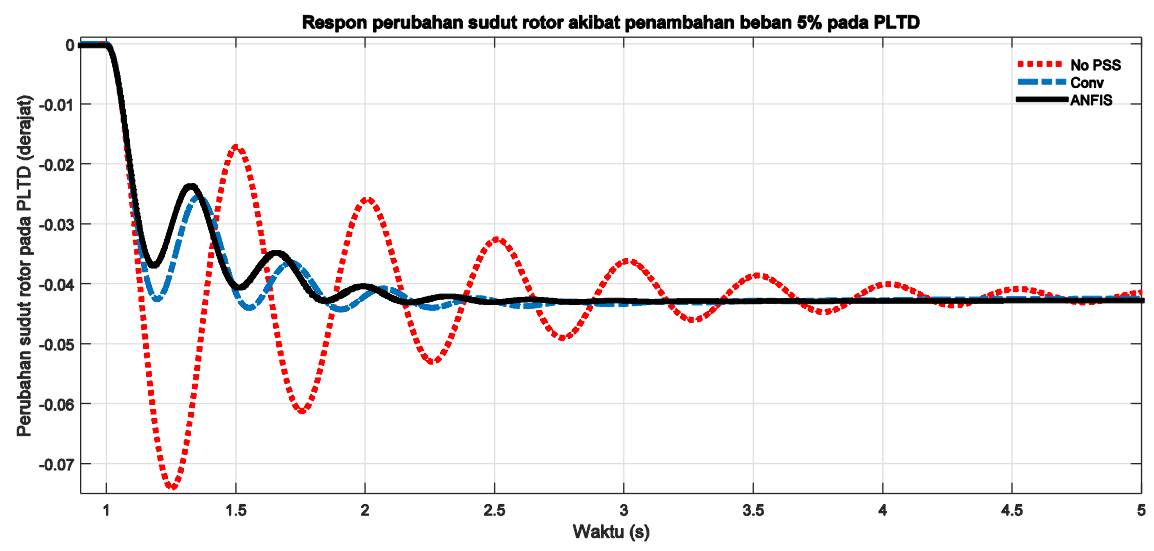

Gambar 5. Perubahan sudut rotor PLTD akibat beban naik 5\% pada bus PLTD

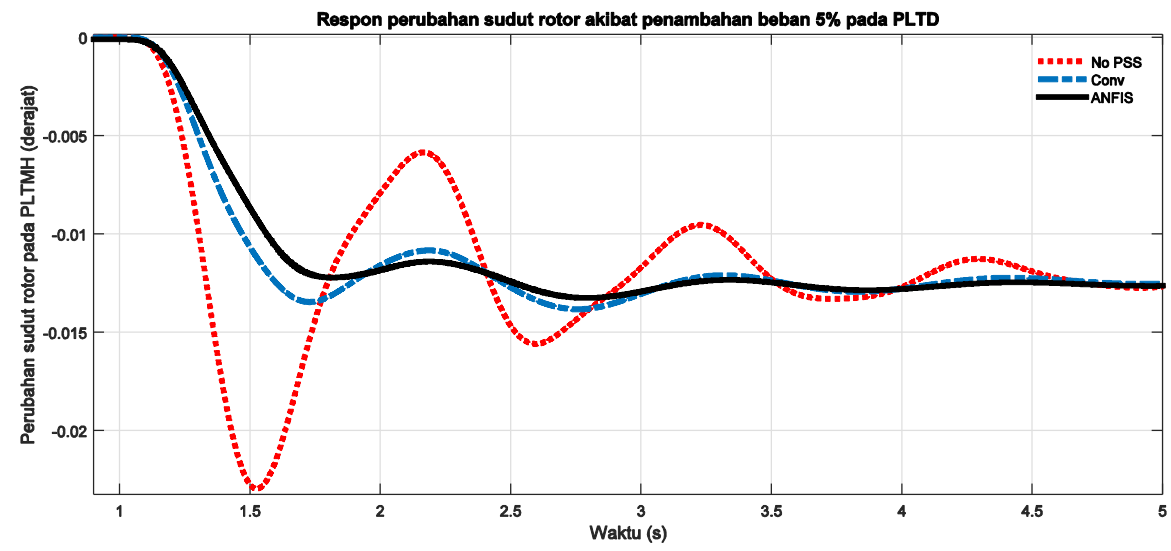

Gambar 6. Perubahan sudut rotor PLTMH diuji dengan kenaikan beban 5\% di bus PLTD

Respon yang dihasilkan untuk sudut rotor adalah seperti Gambar 5 dan Tabel 2, memperlihatkan bahwa respon PSS ANFIS memberikan peak overshoot lebih kecil $\left(-0,0431^{\circ}\right)$ daripada PSS konvensional dan no PSS yang memberikan peak overshoot masing-masing $\left(-0,0443\right.$ dan $\left.-0,074^{\circ}\right)$. Settling time yang diberikan oleh PSS ANFIS adalah pada waktu 3,414 s. Sementara itu, PSS konvensional dan no PSS yang memberikan settling 
time pada waktu masing-masing 3,779 dan lebih lama dari 6 s. Gambar 6 dan Tabel 2 memperlihatkan bahwa respon dari PSS ANFIS adalah menghasilkan peak overshoot lebih kecil daripada PSS konvensional dan no PSS. Juga, settling time yang diberikan oleh PSS ANFIS lebih cepat daripada PSS konvensional dan no PSS.

Tabel 1. Unjuk kerja PSS ANFIS untuk kenaikan beban 5\% pada Bus PLTD untuk respon perubahan kecepatan rotor

\begin{tabular}{|c|c|c|c|c|c|c|}
\hline \multirow{2}{*}{$\begin{array}{c}\text { Respon } \\
\text { perubahan } \\
\text { kecepatan } \\
\text { rotor }(\Delta \omega)\end{array}$} & \multicolumn{2}{|c|}{ No PSS } & \multicolumn{2}{|c|}{ PSS Conv } & \multicolumn{2}{|c|}{ PSS ANFIS } \\
\hline & $\begin{array}{c}M_{p} \times\left(-10^{-4}\right) \\
(\mathrm{rad} / \mathrm{s})\end{array}$ & $\begin{array}{l}t_{s t} \\
(\mathbf{s})\end{array}$ & $\begin{array}{c}M_{p} \times\left(-10^{-4}\right) \\
\quad(\mathrm{rad} / \mathrm{s})\end{array}$ & $\begin{array}{l}t_{s t} \\
(\mathbf{s})\end{array}$ & $\begin{array}{c}M_{p} \times\left(-10^{-4}\right) \\
\quad(\mathrm{rad} / \mathrm{s})\end{array}$ & $\begin{array}{l}t_{s t} \\
(\mathbf{s})\end{array}$ \\
\hline PLTD & 14,97 & $>6$ & 11,39 & 3,26 & 10,05 & 2,91 \\
\hline PLTMH & 2,79 & $>6$ & 1,35 & 3,38 & 0,836 & 3,04 \\
\hline
\end{tabular}

Tabel 2. Unjuk kerja PSS ANFIS untuk kenaikan beban 5\% pada Bus PLTD untuk respon perubahan sudut rotor

\begin{tabular}{|c|c|c|c|c|c|c|}
\hline \multirow{2}{*}{$\begin{array}{c}\text { Respon } \\
\text { perubahan } \\
\text { sudut } \\
\text { rotor }(\Delta \delta)\end{array}$} & \multicolumn{2}{|c|}{ No PSS } & \multicolumn{2}{|c|}{ PSS Conv } & \multicolumn{2}{|c|}{ PSS ANFIS } \\
\hline & $\begin{array}{c}M_{p} \times(-1) \\
\left({ }^{\circ}\right)\end{array}$ & $\begin{array}{l}t_{s t} \\
(\mathbf{s})\end{array}$ & $\begin{array}{c}M_{p} \times(-1) \\
\left({ }^{\circ}\right)\end{array}$ & $\begin{array}{l}t_{s t} \\
(\mathbf{s})\end{array}$ & $\begin{array}{c}M_{p} \times(-1) \\
\left({ }^{\circ}\right)\end{array}$ & $\begin{array}{l}t_{s t} \\
(\mathbf{s})\end{array}$ \\
\hline PLTD & 0,074 & $>6$ & 0,0443 & 3,779 & 0,0431 & 3,414 \\
\hline PLTMH & 0,023 & $>6$ & 0,0138 & 4,051 & 0,0132 & 3,553 \\
\hline
\end{tabular}

\section{Simulasi Kenaikan Beban 5\% pada Bus PLTMH}

Skenario II: Beban di Bus PLTMH dinaikkan sebesar 5\% maka respon yang dihasilkan untuk kecepatan rotor adalah seperti Gambar 7-10, Tabel 3 dan 4. Respon PSS ANFIS memberikan peak overshoot lebih kecil yaitu pada nilai $-0,991 \times 10^{-4} \mathrm{rad} / \mathrm{s}$ daripada PSS konvensional dan no PSS yang memberikan peak overshoot masing-masing sebesar $-1,362$ dan $-2,451 \times 10^{-4} \mathrm{rad} / \mathrm{s}$, seperti yang dapat dilihat pada Gambar 7 dan Tabel 3. Settling time yang diberikan oleh PSS ANFIS adalah pada waktu 4,02 s. Sementara itu, PSS konvensional dan no PSS memberikan settling time pada waktu masing-masing 4,57 dan lebih lama dari 6 s. Untuk Gambar 8 dan Tabel 3 memberi petunjuk bahwa ketika kenaikan beban pada PLTMH 5\%, tidak ada perbaikan respon peak overshoot dan setling time pada PLTMH. Karena PSS dipasang pada PLTD, sedangkan PLTMH tanpa dilengkapi PSS (no PSS). Hal ini menunjukkan PSS pada PLTD tidak memberikan konstribusi perbaikan pada respon PLTMH ketika diuji dengan kenaikan beban 5\% di PLTMH. 


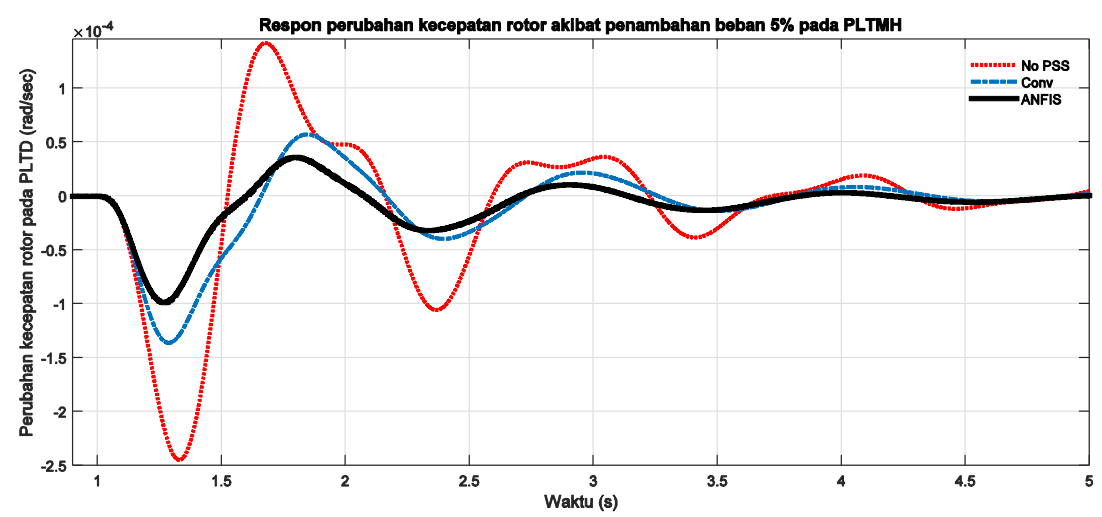

Gambar 7. Perbaikan respon kecepatan rotor PLTMH ketika diuji kenaikan beban 5\% di bus PLTD

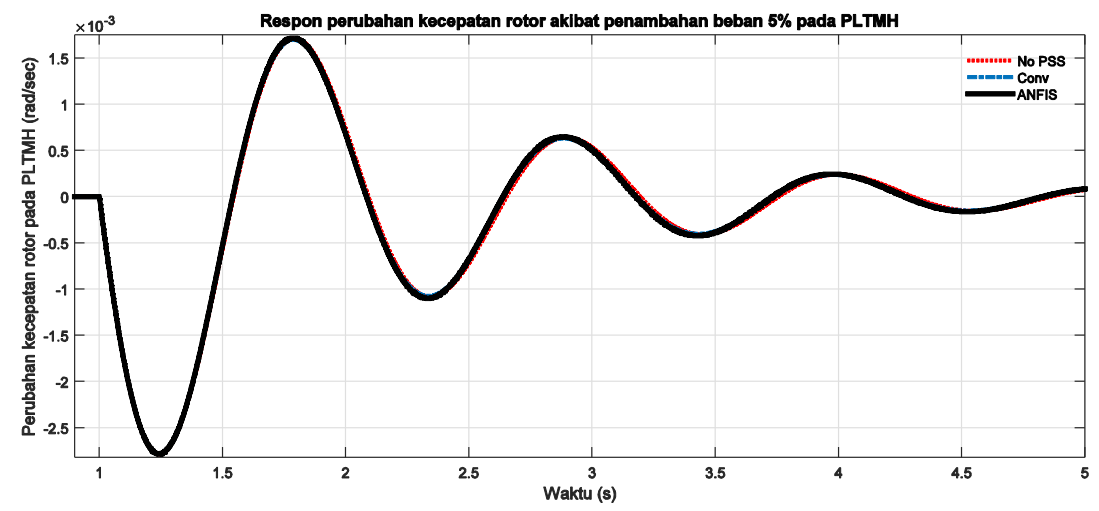

Gambar 8. Perubahan kec. rotor PLTMH akibat beban naik 5\% pada bus PLTD

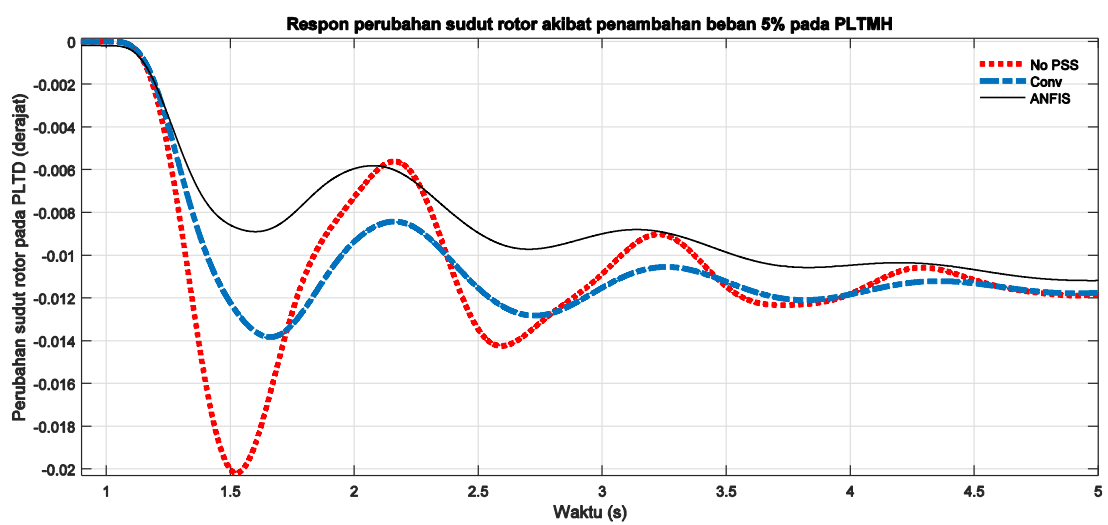

Gambar 9. Perubahan sudut rotor PLTMH ketika beban dinaikkan 5\% di bus PLTD 


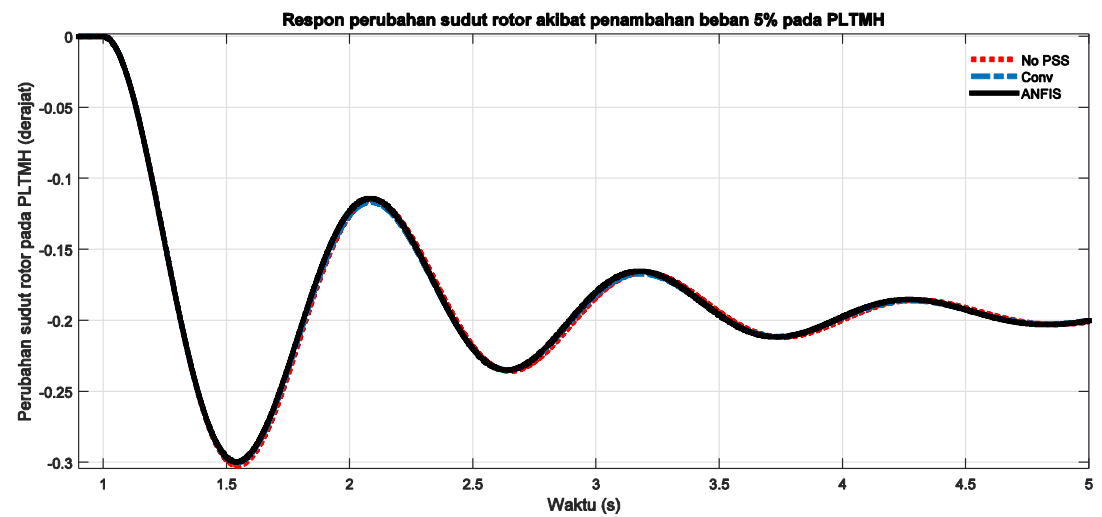

Gambar 10. Perubahan sudut rotor PLTMH diuji dengan beban naik 5\% di bus PLTD

Respon yang dihasilkan untuk sudut rotor adalah seperti Gambar 9 dan Tabel 4, memperlihatkan bahwa respon PSS ANFIS memberikan peak overshoot lebih kecil $\left(-0,012^{\circ}\right)$ daripada PSS konvensional dan no PSS yang memberikan peak overshoot masingmasing $\left(-0,0138\right.$ dan $\left.-0,0202^{\circ}\right)$. Settling time yang diberikan oleh PSS ANFIS adalah pada waktu 5,153 s. Sementara itu, PSS konvensional dan no PSS yang memberikan settling time pada waktu masing-masing 5,233 dan lebih lama dari 6 s. Gambar 10 dan Tabel 4 menunjukkan bahwa respon goyangan PLTMH akibat kenaikan beban di bus PLTMH sangat besar, sehingga aksi PSS pada PLTD tidak dapat mengurangi secara signifikan goyangan PLTMH untuk kenaikan beban di bus PLTMH. Deviasi sudut rotor dari PLTMH masih berosilasi dan settling time dicapai lebih dari 6 detik.

Tabel 3. Unjuk kerja PSS ANFIS untuk kenaikan beban 5\% pada Bus PLTMH untuk respon perubahan kecepatan rotor

\begin{tabular}{|c|c|c|c|c|c|c|}
\hline \multirow{2}{*}{$\begin{array}{c}\text { Respon } \\
\text { perubahan } \\
\text { kecepatan } \\
\text { rotor }(\Delta \omega)\end{array}$} & \multicolumn{2}{|c|}{ No PSS } & \multicolumn{2}{|c|}{ PSS Conv } & \multicolumn{2}{|c|}{ PSS ANFIS } \\
\hline & $\begin{array}{c}M_{p} \times\left(-10^{-4}\right) \\
(\mathrm{rad} / \mathrm{s})\end{array}$ & $\begin{array}{l}t_{s t} \\
(\mathbf{s})\end{array}$ & $\begin{array}{c}M_{p} \times\left(-10^{-4}\right) \\
(\mathrm{rad} / \mathrm{s})\end{array}$ & $\begin{array}{l}t_{s t} \\
(\mathbf{s})\end{array}$ & $\begin{array}{c}M_{p} \times\left(-10^{-4}\right) \\
\quad(\mathrm{rad} / \mathrm{s})\end{array}$ & $\begin{array}{l}t_{s t} \\
(\mathbf{s})\end{array}$ \\
\hline PLTD & 51 & $>6$ & 1,362 & 4,57 & 0,991 & 4,02 \\
\hline PLTMH & 27.88 & $>6$ & 27,83 & $>6$ & 27,82 & $>6$ \\
\hline
\end{tabular}

Tabel 4. Unjuk kerja PSS ANFIS untuk kenaikan beban 5\% pada Bus PLTMH untuk respon perubahan sudut rotor

\begin{tabular}{ccccccc}
\hline Respon & \multicolumn{2}{c}{ No PSS } & \multicolumn{2}{c}{ PSS Conv } & \multicolumn{2}{c}{ PSS ANFIS } \\
\cline { 2 - 7 } $\begin{array}{c}\text { perubahan } \\
\text { sudut }\end{array}$ & $\boldsymbol{M}_{p} \times(-\mathbf{1})$ & $\boldsymbol{t}_{\boldsymbol{s t}}$ & $\boldsymbol{M}_{\boldsymbol{p}} \times(\mathbf{- 1})$ & $\boldsymbol{t}_{\boldsymbol{s t}}$ & $\boldsymbol{M}_{p} \times(-\mathbf{1})$ & $\boldsymbol{t}_{\boldsymbol{s t}}$ \\
rotor $(\boldsymbol{\Delta} \boldsymbol{\delta})$ & $\left({ }^{\circ}\right)$ & $(\mathbf{s})$ & $\left({ }^{\circ}\right)$ & $(\mathbf{s})$ & $\left({ }^{\circ}\right)$ & $(\mathbf{s})$ \\
\hline PLTD & 0,0202 & $>6$ & 0,0138 & 5,233 & 0,012 & 5,153 \\
PLTMH & 0,3023 & $>6$ & 0,3003 & $>6$ & 0,2995 & $>6$ \\
\hline
\end{tabular}




\section{KESIMPULAN}

Penelitian ini adalah mendesain PSS ANFIS dan diaplikasikan pada sistem kelistrikan Lombok (SKL) dengan memperhitungkan pembangkit listrik mikro hydro. PSS ANFIS dilatih dibentuk melalui proses pelatihan dengan data dari PSS konvensional. Berdasarkan hasil pengujian diperoleh bahwa PSS ANFIS dapat memperbaiki stabilitas sinyal kecil untuk SKL. Hal ini dapat dilihat pada parameter peak overshoot untuk PSS ANFIS lebih kecil daripada peak overshoot untuk PSS konvensional untuk semua skenario. Juga diperoleh bahwa settling time untuk PSS ANFIS lebih pendek dari settling time untuk PSS konvensional.

\section{Ucapan Terimakasih}

Kami menyampaikan ucapan terima kasih kepada Universitas Mataram atas dukungan pendanaan Penelitian PNBP Sumber Dana BLU Universitas Mataram Tahun 2020.

\section{DAFTAR PUSTAKA}

PLN, 2005. Master plant Sistem Kelistrikan Lombok. PT. PLN (Persero) Wilayah NTB.

Canizares, C., 2000. Voltage stability assessment: Concepts, practices and tools. IEEE-PES Power System Stability Subcommitte Special Publication.

Donnelly, M.K., dkk., 1996. Impacts of the distributed utility on transmission system stability. IEEE Trans. on Power Syst. Stability, vol. 11 no. 2, pp. 741-746.

De Mello, F.P. dan Concordia, C., 1969. Concept of synchronous machine stability as effected by excitation control. IEEE Trans. on Power Syst. PAS-88(4).

Genc, I., Schattler, H., Zaborszky, J., 2003. Hopf bifurcation related coherent oscilations between clusters in the bulk power system. IEEE Bologna Power Tech Conference.

Guttromson, R.T., 2002. Modelling distributed energy resource dynamics on the transmission system. IEEE Trans. on Power Syst. 17(4): 1148-1153.

Ginarsa, I.M., 2001, Analisis respon frekuensi untuk penalaan power sistem stabilizer pada sistem multimesin. Tesis UGM. Yogyakarta.

Ginarsa, I.M., Soeprijanto, A., Purnomo, M.H., 2013. Controlling chaos and voltage collapse using an ANFIS-based composite controller-static var compensator (CC-SVC) in power systems. IJEPES Journal. vol. 46, pp. 79-88.

Ginarsa, I.M. dan Zebua, O., 2014. Stability improvement of single machine using ANFISPSS based on feedback-linearization. Telkomnika Journal. 12(2): 315-324.

Ginarsa, I.M., dkk., 2018. Desain power system stabilizer berbasis fuzzy tipe-2 untuk perbaikan stabilitas mesin tunggal. Jurnal Rekayasa Elektrika. 14(1): 1-8.

Ginarsa, I.M., dkk., 2018. ANFIS-based controller to regulate firing angle of inverter in average value model-high voltage direct current transmission system. Procs. of ICGTEIS, Bali: 1-6.

Ginarsa, I.M., dkk., 2019. Simulation of ANFIS controller to line commutation based on current source converter in high voltage direct current. Procs. of CENCON, Yogyakarta. 16-17 Oct. 
Ginarsa, I.M., dkk., 2020. Transient response improvement of direct current using supplementary control based on ANFIS for rectifier in HVDC. IJPEDS Journal. 11(4): 2107-2115.

Knazkins, V., 2004. Stability of power system with large amounts of distributed generation. KTH Elektrical Engineering. Sweden.

Kundur, P., 1994. Power systems stability and control. McGraw-Hill, Inc.

Lasseter, R.H., 2003. Distributed generation. Power Systems Eng. Research Centre.

llic, M., Galiana, F. dan Fink, L., 1998. Power systems restructuring. Kluwer Academic Pub.

Ilic, M. dan Zaborszky, J., 2000. Dynamic and control of large electric power systems. John Wiley \& Sons Inc.

Muljono, A.B., Ginarsa, I.M. dan Nrartha, I.M.A., 2015. Dynamic stability improvement of multimachine power systems using ANFIS-based power system stabilizer. Telkomnika 13(4): 1170-1178.

Muljono, A.B. dan Nrartha, I.M.A., 2009. Analisis pengaruh unit pembangkit tersebar terhadap stabilitas dinamis sistem tenaga. Majalah Ilmiah Teknologi Elektro. 8(1): $52-57$.

Narang, A., 2006. Impact of large-scale distributed generation penetration on power system stability. CANMET Energy Technology Centre, Canada.

Nikman, T,. Ranjbar, A.H. dan Shirani, A.R., 2003. Impact of distributed generation on volt/var control in distribution networks. IEEE Bologna Power Tech Conference.

Nrartha, I.M.A. dan Muljono, A.B., 2010. Pengaruh power system stabilizer pada system tenaga listrik dengan unit pembangkit tersebar. Majalah Ilmiah Teknologi Elektro. 9(1): 12-21.

Slootweg, J.G. dan Kling, W.L., 2002. Impacts of Distributed Generation on Power System Transient Stability. Power Engineering Society Summer Meeting, 2: 862-867.

Soeprijanto, A., 1995. Metoda sederhana penalaan power system stabilizer. Tesis ITB, Bandung.

William, D dan Stevenson, Jr., 1982. Analisis sistem tenaga listrik. Erlangga, Jakarta. 